\title{
THE EFFECT OF PRO-ENTREPRENEURSHIP ARCHITECTURE ON ORGANISATIONAL OUTCOMES
}

\author{
Boris Urban \\ Graduate School of Business Administration, Wits Business School, \\ Faculty of Commerce, Law and Management, University of Witwatersrand, \\ PO Box 98, Wits 2050, South Africa \\ E-mail: boris.urban@wits.ac.za
}

Received 09 March 2011; accepted 21 June 2011

\begin{abstract}
Recent years have seen considerable work at the interface between business, management, entrepreneurship and strategy and as a result, new research domains have appeared including corporate entrepreneurship and entrepreneurial strategy. The purpose of this article is to understand the effect that corporate entrepreneurship strategy has on firms to revitalize, reconfigure resources and transform into firms that are ready to compete in the global economy. Empirical tests are conducted to determine to what extent elements of pro-entrepreneurship architecture are able to predict development capability, strategic repositioning, and growth based outcomes. A first-phase survey is conducted to verify the presence and strength of entrepreneurial orientation while the second phase of the study identifies elements of organizational architecture able to predict firm outcomes. The main contribution of this article is that firms resourcing and rewarding policies, as well as cultural and structural orientations, derived from a corporate entrepreneurship strategy, play a significant role in realizing desired outcomes. The study has important implications for emerging economies where growth is often the primary goal of organizations, and where corporate entrepreneurship can be critical for firm profitability and survival.
\end{abstract}

Keywords: strategy, business outcomes, corporate entrepreneurship, organizational elements.

Reference to this paper should be made as follows: Urban, B. 2012. The effect of proentrepreneurship architecture on organisational outcomes, Journal of Business Economics and Management 13(3): 518-545.

JEL Classification: L14, L25, L26.

\section{Introduction}

The present business environment is filled with many contradictions where the dominant logic (Bettis, Prahalad 1995) of a firm previously considered optimal, may well be inappropriate. Recent decisions have been made to restructure the business and financial sectors to make capitalism work again, specifically to guard against reckless disregard of uncertainty, while reviving innovativeness in business (Arslan, Karan 2009; Phelps 2009). One way of creating a dynamic dominant logic is to make entrepreneurship the basis upon which the organization is conceptualized (Morris et al. 2008). The scope of 
corporate entrepreneurship is widening as organizations that have not previously been recognized as entrepreneurial begin to embrace entrepreneurship in order to survive and succeed in increasingly competitive and financially constrained environments (Antoncic 2006; Grüner 2006; Phan et al. 2009; Urban 2010b). At the level of the organization, entrepreneurship can provide direction to the company's entire operation, serving as an integral component of a firm's strategy, and possibly as the core component of corporate strategy (Jumpponen et al. 2008; Morris et al. 2008).

Recent years have seen considerable work at the interface between entrepreneurship and strategy (e.g., Latham 2009; Meyer, Heppard 2000; Newbert et al. 2007). As a result, new research domains have appeared including corporate entrepreneurship (Sharma, Chrisman 1999), corporate venturing (Burgelman 1983), and entrepreneurial strategy (Eisenhardt et al. 2000). All of these domains address entrepreneurial behaviors that are strategic, yet their definitional differences are subject to debate, and the relationships among them remain unspecified (Schindehutte, Morris 2009). Despite these definitional controversies what emerges is that the integration of entrepreneurship with strategy relies on the critical aspects of entrepreneurial strategy and a strategy for entrepreneurship (Kuratko, Audretsch 2009; Morris et al. 2008).

Entrepreneurship and its relationship with strategy is studied extensively within organizations and has been conceptualized as a fundamental posture, instrumentally important to strategic innovation, particularly under shifting external environmental conditions (Camisón, Villar-López 2010; Ireland, Webb 2007; Knight 1997). Research in the field of entrepreneurship tends to focus on small organizations as far as venturing is concerned or on large organizations when it comes to corporate entrepreneurship. However, small businesses can adopt entrepreneurial behavior long after their creation by constantly scanning for opportunities (Merz, Sauber 1995; Messeghem 2003). In this paper it is argued that the nexus between entrepreneurship and strategy is equally relevant to small and medium size firms, who are usually more vulnerable to external influences since their competitive advantage tends to be less sustainable than large firms within the changing environment (Jumpponen et al. 2008; Ketchen et al. 2007; Russell, R. D., Russell, C. J. 1992; Urban 2010a).

Recently, as a way toward the future in strategy research, there has been a call to cast small business as a "main character at the centre of the action in technology and innovation" (Tan et al. 2009: 234). Moreover, corporate entrepreneurship has been emphasized as the key for emerging economy firms to revitalize, reconfigure resources, and transform into market-orientated firms that are ready to compete in the global economy (Jumpponen et al. 2008; Zahra et al. 2000). Thus far, there has not been much work on corporate entrepreneurship in transition economies and emerging markets, as contrasted to entrepreneurship studies at the individual level (Zahra et al. 2000). Recognizing that entrepreneurial actions are the bedrock of entrepreneurial processes and behavior for both large and small firms, and that these behaviors may be critical to the long term vitality of an economy (Stevenson 1983), it is important to facilitate the empirical study of them in an under researched, emerging market environment. 
This article expands upon the notion that corporate entrepreneurship strategy can be regarded as a specific type of strategy, which is relevant to small businesses, where firms must significantly display the three foundational elements of: an entrepreneurial strategic vision, a pro-entrepreneurship organizational architecture, and entrepreneurial processes and behavior as manifested throughout the organization (Ireland et al. 2009). Subsequently, corporate entrepreneurship can be very suitable with the reality of small firms (Aloulou, Faylolle 2005). Building in this research direction the focus is on the set of organizational locations from which entrepreneurial behavior and processes may emerge (Zahra et al. 1999). While several firms may be entrepreneurial in one or a few respects, few are entrepreneurial throughout the spectrum (Morris et al. 2008).

Phase one of this study aims to capture and verify the presence and strength of an entrepreneurial strategic vision as a defining mind-set shared by the owner managers, with the entrepreneurial orientation (EO) construct. Firms with higher levels of EO would reflect consistent behavior required to enact a corporate entrepreneurship strategy as captured through entrepreneurial processes and behavior (Anderson et al. 2009; Dess, Lumpkin 2005). Building on data gathered in the first phase of this study, the second phase tests which elements of the pro-entrepreneurship organizational architecture are related and are able to predict organizational-level consequences of corporate entrepreneurship strategy. Three principal outcomes are specified as: (1) capability development, (2) strategic repositioning, and (3) a third set of separate outcomes, in the form of growth indicators. The justification for including these growth outcomes is that theoretical arguments from the resource- and knowledge-based views of the firm (Barney 1991; Kogut, Zander 1992) clearly suggest that growth would only enhance profitability if the expansion is aligned with the firm's unique resources and competences (Steffens et al. 2009).

The article is structured to first delineate the topics under investigation in order to allow for salient variables to be operationalised. Specific linkages between the various components of corporate entrepreneurship strategy are hypothesized which are statistically tested. Implications and recommendations follow based on the empirical findings.

\section{Corporate entrepreneurship}

A longstanding literature has conceptualized corporate entrepreneurship $(\mathrm{CE})$ as a multidimensional phenomenon which incorporates the behavior and interactions of the individual, organizational, and environmental elements within organizations (Covin, Miles 2007; Dess et al. 1999; Kuratko et al. 1993; Morris et al. 1994; Morris, Kuratko 2002; Zahra 1993). CE refers to an organization's commitments to pursuing new opportunities, creating new units or businesses, innovativeness in terms of products, services and processes, strategic self renewal, constructive risk-taking and pro-activeness (Antoncic, Hisrich 2004; Kuratko et al. 2001).

Entrepreneurship in corporations has been labeled in many different ways, with conceptual roots in innovation entrepreneurship (Schumpeter 1934) and innovation management (Drucker 1979). More recent terms include intrapreneurship (Antoncic, Hisrich 2001; Kuratko 2002; Pinchot 1985), venture entrepreneurship (Tang, Koveos 2004), 
corporate intrapreneurship (Dess et al. 2003), strategic entrepreneurial posture (Covin, Slevin 1989), and internal corporate venturing (Hornsby et al. 2002); these not being merely differences in nomenclature, but each having specific meaning and focus. CE which includes strategic renewal (organizational renewal involving major strategic and/or structural changes), innovation (the introduction of something new to the marketplace), and corporate venturing (corporate entrepreneurial efforts that lead to the creation of new companies within the corporate company), are all important and legitimate parts of the CE process (refer to Covin, Miles 1999; Kuratko, Welsch 2001; Morris, Kuratko 2002). Sharma and Chrisman (1999) and Geisler (1993) view CE as the process whereby an individual or group of individuals, in association with an existing company, create a new company or instigate renewal or innovation within that company, or in a family business (Kellermanns, Eddleston 2006).

Lumpkin and Dess (1996) argue that CE has two primary aims: the creation and pursuit of new venture opportunities and strategic renewal. These aims allow firms to gain a competitive advantage by encouraging innovation at all levels in the organization. A model by Kuratko, Hornsby and Goldsby (2004) designed to inject entrepreneurship into organizations demonstrates that sustainability is contingent upon individual members undertaking innovative activities, which stimulate positive perceptions in executive management, which in turn leads to further allocation of necessary organizational support and resources. Top-level managers are responsible for putting into place pro-entrepreneurship organizational architectures, i.e., where the workplace exhibits structural, cultural, resource, and system attributes that encourage entrepreneurial behavior, both individually and collectively (Morris et al. 2008; Schindehutte et al. 2000). Similarly, Covin and Slevin's (1991) conceptual model of entrepreneurship as firm behavior indicates that a firms entrepreneurial intensity has a direct and positive influence on company performance because it is interwoven within the organizations vision, strategies, objectives, structures and operations (Burns 2004).

Taken as a whole, theoretical argument and empirical evidence prove that the CE literature uses a firm behavior perspective to understand entrepreneurship and that firm-level behavior can be managed by the creation of strategies, resources and structure.

For the purposes of this paper it is argued that using a firm behavior perspective to understand entrepreneurship is meaningful and the advantages of studying small businesses from this perspective are: (1) firm behavior, as strategy, structure, and performance, is more clearly understood than when only studying the individual entrepreneur; (2) firm behavior is more easily measured that at the individual level; and (3) firm behavior is more manageable (Covin, Miles 2007).

\section{Strategic entrepreneurship}

Strategic entrepreneurship (SE) is defined as "the integration of entrepreneurial (i.e., opportunity-seeking behavior) and strategic (advantage-seeking behavior) perspectives in developing and taking actions designed to create wealth" (Hitt et al. 2002: 481). Covin and Kuratko (2008) discuss SE within the realm of CE. Ireland et al. (2009: 21) define "CE strategy as a vision-directed, organization-wide reliance on entrepreneurial 
behavior that purposefully and continuously rejuvenates the organization and shapes the scope of its operations through the recognition and exploitation of entrepreneurial opportunity".

Not only can entrepreneurship serve as the dominant logic of a company, but it also plays an important role in the firm's strategy. Strategy research has focused previously on small and medium enterprises (SMEs), specifically in terms of how small business managers make certain strategic decisions based on available resources (Borch et al. 1999), and that pursuing innovation allows SMEs to preserve their creativity and flexibility while mitigating the inherent liability of smallness (Ketchen et al. 2007).

Guth and Ginsberg (1990) provide a framework for fitting CE into strategic management, where CE can also be manifested as an identifiable strategy, as inferable from the presence of patterns of entrepreneurial behavior and an overall perspective that lends meaning to and directs that activity (Mintzberg 1987), and influences its financial outcomes (Zahra 1991). Moreover, SE has been conceptualized as a value-creating union in which a balance is sought between exploration and exploitation (Ireland et al. 2003), and which centers on the notion of an opportunity space and a paradigm built around forms, flows, and functions. Companies engaging in some level of entrepreneurial activity do not always integrate those activities into their core strategies. While corporate venturing entails company involvement in the creation of new business, SE corresponds to a broader array of entrepreneurial initiatives, which involve organizational consequential innovations adopted to pursue competitive advantage (Morris et al. 2008). Thus, while evidence of entrepreneurial initiatives can be located in many and perhaps most established organizations, the mere presence of those initiatives should not be interpreted as evidence that a CE strategy is in use (Ireland et al. 2009).

In Ireland's et al. (2009) CE strategy model, pro-entrepreneurship architecture is the organizational context through which the entrepreneurial strategic vision is translated into specific entrepreneurial processes and behaviors. The success of a CE strategy is more probable when a firm has the skills required to structure (accumulate and strategically divest), bundle (successfully combine), and leverage (mobilize and deploy) its resources (Sirmon et al. 2007). It is conceivable that in many situations a firm would have to excel along all or most of the dimensions in order to achieve the ability to create superior value. This would indicate that there are many different routes to achieve high entrepreneurial performance. One such route, where entrepreneurship is manifested across the organization by implementing a particular strategy, is entrepreneurial orientation (EO). EO has been used extensively to describe firms exhibiting an entrepreneurial strategic vision and entrepreneurial behavior and processes.

\section{Entrepreneurial orientation}

Extensive research is prevalent on the entrepreneurial orientation (EO) construct. Prior theory and research (Covin, Slevin 1989; Khandwalla 1977; Lee, Peterson 2000; Lumpkin, Dess 1996; Miller, Friesen 1983, 1984) indicates that an EO is a key ingredient for organizational success, and has been previously linked to increased performance (Zahra, 
Covin 1995; Wiklund, Shepherd 2003). Research provides theoretical support for the EO construct, in both the fields of entrepreneurship and strategic management (Marino et al. 2002). Anderson, Covin, and Slevin (2009) confirm the direct effect of EO on strategic learning capability, and mediating effects for structural organicity, market responsiveness, and strategy formation.

EO incorporates firm-level processes, practices and decision-making styles (Lumpkin and Dess, 1996) where "entrepreneurial behavioral patterns are recurring" (Covin, Slevin 1991: 7). The theoretical basis of the EO construct lies in the assumption that all firms have an EO, even if levels of EO are very low (Wiklund 1999). Extensive research confirms that EO has three dimensions: innovativeness, risk taking, and proactiveness (Covin, Slevin 1989, 1991, 1997; Kreiser et al. 2002; Lumpkin, Dess 1996, 2001). Innovativeness is the fundamental posture of an entrepreneurial organization in terms of developing new products or inventing new processes (Schumpeter 1934; Drucker 1979). Innovativeness as an attribute describes an organizations' willingness to add newness with added value. Risk-taking is associated with the willingness to commit significant resources to opportunities and to take calculated business risks (Aloulou, Faylolle 2005). Proactiveness is perseverance in ensuring initiatives are implemented, and is concerned with adaptability and tolerance of failure. The dimensions have been extensively documented, and according to Lumpkin and Dess (1996), all the dimensions are central to understanding the entrepreneurial process, although they may occur in different combinations, depending on the type of entrepreneurial opportunity the firm pursues (Bingham et al. 2007; Urban 2008).

According to Ireland et al. (2009), EO may be subsumed within the CE strategy (which specifies where to look for evidence of entrepreneurship within the organization). $\mathrm{CE}$ strategy is distinct from prior models of entrepreneurial phenomena (e.g., EO) in established organizations in four important aspects: the behavioral dimension, the locus of entrepreneurship, the philosophical justification, and $\mathrm{CE}$ as a unique and identifiable strategy. As such, it has been suggested that firms adopting a CE strategy should carefully analyze their ability to think strategically when acting entrepreneurially (Kuratko et al. 1993; Kuratko, Welsch 2001).

\section{Elements of pro-entrepreneurship architecture}

Salient elements of CE strategy that encourage entrepreneurial processes and behavior, can be traced to Stevenson's (1983) generic forms of entrepreneurial behavior, which he categorized along six dimensions: (1) strategic orientation, (2) commitment to opportunity, (3) commitment of resources and control of resources, (4) management structure, (5) reward philosophy, he later added two more dimensions; (6) entrepreneurial culture and growth orientation (Brown et al. 2001; Stevenson 1983; Stevenson, Gumpert 1985; Stevenson, Jarillo 1986, 1990).

These are described as follows by Brown et al. (2001) and Stevenson (1983).

(1) Strategic orientation describes what factors drive the creation of strategy. As opportunities drive strategy, almost any opportunity is relevant to the firm. Once an 
opportunity is identified, resources are needed to exploit it. The resources are the starting point and only opportunities that relate to existing resources are relevant to the firm. Related terms of visionary leadership / entrepreneurial leadership are complementary to the creation of strategy.

(2) Commitment to opportunity is related to strategic action. Research on entrepreneurial behaviors and opportunity is well documented, where opportunity focused firms are innovate and creative where the propagation of new ideas are encouraged.

(3) Commitment of resources and control of resources. An entrepreneurial firm attempts to maximize value creation by exploiting opportunities while minimizing the resources required especially firm resources. In this effort the firm may "test the waters" by committing small amounts of resources in an incremental manner with minimal (risk) exposure at each step. This allows the firm to stop and change direction at any step, if and when circumstances deem necessary. The second component of Stevenson's (1983) opportunistic view of resources maintains that firms further reduce the resources they own and become skilled at the use of other people's resources including financial capital, intellectual capital, skills, competencies, etc. Stevenson (1983) calls this dimension Control of resources. When a combination of resources enables an organization to accomplish a task, those resources are referred to as a capability.

(4) Management structure of the entrepreneurial organization is organic. While many structural attributes have been empirically linked to innovation activity in organizations, perhaps the single aspect of structure that best defines entrepreneurial organizations is structural organicity. Organicity is the extent to which the organization's overall form can be characterized as organic or mechanistic. Greater organicity implies a proclivity toward such qualities as decentralized decision making, low formality, wide spans of control, expertise- (vs. position)-based power, process flexibility, free-flowing information networks, and loose adherence to rules and policies. Greater mechanization implies the opposite.

(5) Reward Philosophy. Entrepreneurially managed firms tend to base compensation on how individuals contribute to value creation. The organic firm structure, as discussed, is conducive to this evaluation because it is designed for independent action and accountability. Organizational systems can have a direct and immediate effect on the occurrence of entrepreneurial behavior. In particular, whether or not the reward system encourages risk taking and innovation has a direct effect on tendencies to behave in an entrepreneurial manner. Reward systems are, of course, part of the organizational architecture top executives assist in creating. Whether formal or informal, reward systems will likely be influenced by the vision executives articulate for their organizations.

(6) Growth orientation and entrepreneurial culture. Firms with an entrepreneurial culture encourage ideas, experimentation and creativity. The specific attributes of organizational cultures that support entrepreneurial behavior has been the focus of considerable theorizing as well as empirical research. Importantly, top-level managers' words and actions can significantly influence organizational culture. Therefore, as top-level managers articulate and act upon an entrepreneurial strategic vision, it 
will likely affect the organization's cultural attributes, encouraging the formation of cultural norms favoring entrepreneurship. These norms may, in turn, reinforce organizational members' commitment to the entrepreneurial strategic vision.

Some scholars have suggested that organizational processes are not just crucial to strategy, but rather are the strategy of firms, especially in entrepreneurial firms and dynamic markets. In contrast, the strategic logic of opportunity view suggests that organizational processes positions the firm for opportunity flows (Bingham et al. 2007). Businesses which incorporate innovation into their vision by relying on entrepreneurial strategies and actions, understand that innovation is at the core of an entrepreneurial organization. It is around this core that other elements of the organization such as strategy, management style and structure are built. Corporate environments supportive of entrepreneurship must provide appropriate reward systems, top management support, explicit goals and appropriate organizational values which signal to employees that entrepreneurial behavior action is desirable. For CE to become a meaningful conduit for a corporation's value creation activities it cannot be confined to a specialist function within the organization. A pro-entrepreneurship organizational architecture is not a unique organizational form but an internal environment or organizational context exhibiting certain attributes that individually and collectively encourage entrepreneurial behavior. It involves integrating hardware elements (e.g. characteristics of organizational structure) with software elements (e.g. culture and climate) (Covin, Slevin 2002). Pro-entrepreneurship organizational architectures are likely to take shape when there is an entrepreneurial strategic vision endorsed by top management that encourages entrepreneurial thought and action throughout the organization (Bartlett, Goshal 1996; Morris, Kuratko 2002; Muzyka 1995).

\section{Consequences of corporate entrepreneurship strategy}

Consequences of $\mathrm{CE}$ are primarily concerned with the degree to which using a CE strategy results in acceptable (or better) current performance and portends the possibility of acceptable (or better) future performance, where performance is defined in terms of the outcomes of interest. The CE model (Ireland et al. 2009) emphasizes organizational-level outcomes of CE strategy as: (1) capability development, and (2) strategic repositioning. Enhanced competitive capability, in particular, often results from the exploitation of entrepreneurial opportunities. Competitive capability is the capacity of firms to create and sustain economically viable industry positions (Nelson 1991; Teece et al. 1997). Competitive capability is created as organizations use entrepreneurial initiatives to explore new technologies or product-market domains or exploit existing technologies or product-market domains. Regarding strategic repositioning, the very act of implementing CE strategy through entrepreneurial behaviors can (1) place the firm (or portions thereof) in a new position within its pre-existing product-market domain(s), (2) alter the attributes of that domain(s), and/or (3) position the firm within a new product-market domain(s).

A third set of outcomes is used for the present study, particularly as a thoughtful analysis of how growth might reflect a successful CE strategy, and meet the principal outcomes 
of capability development and strategic repositioning, holds much promise. A multidimensional approach to capturing performance, as advocated by Wiklund and Shepherd (2003), is useful, particularly as the outcomes may be uniquely associated with the various organizational architecture elements. Successful firms achieve high performance both in sales growth and profitability, with different developmental pathways for young firms (Steffens et al. 2009). Including growth measures as consequences of CE strategy will allow for an integration of "growth as a central role in entrepreneurship" perspective with the prominent view of "strategic management as achieving competitive advantage" (Steffens et al. 2009: 126). It has been noted that differences in growth measures have led to different relationships among constructs, with a reduction in the appropriateness of accumulating knowledge across studies. Shepherd and Wiklund's (2009) findings provide an explanation for the limited progress of general growth theories and help establish appropriate boundary conditions for growth theories. To investigate the appropriateness of knowledge accumulation across studies using different measures of growth, Shepherd and Wiklund (2009) conduct analyses on all Swedish firms incorporated during the 1994 to 1998 period (68,830 firms) and track their growth over their first six years of existence. In the first instance they report that for all indicators of absolute growth (absolute employee, sales, profit, asset, and equity growth), there is high concurrent validity between these measures, when calculated using a 1-year time span and a 3-year time span. However for combined relative and absolute measures of all growth indicators, low concurrent validity was found. These findings suggest that researchers can have confidence in accumulating knowledge across absolute measures that use a 1-year time span and a 3-year time span (Shepherd, Wiklund 2009).

\section{Hypothesis rationale}

Consistent with the strategic entrepreneurship concept (Ireland et al. 2003; Ireland, Webb 2007), and the status of the field's knowledge about corporate entrepreneurship as strategy (Ireland et al. 2009) it is argued that corporate entrepreneurship strategy implies that a firm's strategic intent (Hamel 2000; Hamel, Prahalad 1989) is to continuously and deliberately leverage entrepreneurial opportunities (Shane, Venkataraman 2000) for growth- and competitive advantage-seeking purposes.

Building on past research and in line with theoretical underpinnings, where the success of a CE strategy is more probable when a firm has the skills required to structure (accumulate and strategically divest), bundle (successfully combine), and leverage (mobilize and deploy) its resources, various individual elements of organizational architecture are hypothesized to have a positive influence on organizational outcomes.

More specifically, this study empirically tests to what extent elements of pro-entrepreneurship architecture are able to predict firm outcomes.

Hypothesis: The (a) degree of strategic orientation and structural organicity, (b) the strength of cultural norms favoring entrepreneurial behavior, (c) the strength of the organization's commitment to resources and growth, and (d) the extent to which the organizational reward systems encourage entrepreneurial behavior are positively 
related to (a) the strength of the organization's competitive capability and (b) the realization of strategic repositioning, (c) to sales growth, (d) higher employee growth, and (c) equity growth.

Based on the theoretical and empirical evidence taken together, it has been argued throughout this article that a pro-entrepreneurship organizational architecture is likely to be facilitated by a combination of elements, where these theoretically-congruent combinations (Green et al. 2008) are expected to be significantly associated with firms' outcomes. Since there is reason to believe that these elements may have different effects on the outcomes, it is argued that an increased understanding of the association between these elements and outcomes can only be understood by regressing the various elements on each of the specified outcomes.

\section{Methodology}

This section involved trying to identify samples of firms that exhibit CE strategies to various degrees (thus minimizing the restriction of range problem within the sample). This was daunting as: (1) CE strategies may not be robust in firms, and (2) firms with highly entrepreneurial CE strategies may be few in number, as continuously employing entrepreneurial CE strategies may render these firms vulnerable to collapse (Ireland et al. 2009). To counter-act such sample identification challenges, a two phase research procedure which included a preliminary sample screen, was relied upon.

The first phase served as a screening process to allow for identifying SMEs whose actions were entrepreneurial. To this end, as previously mentioned, the presence of an EO as inferred from evidence of organizational behavior reflecting the risk-taking, innovativeness, and proactiveness, which served as initial selection criteria. It is important to note that by contrast, the CE strategy treats EO as but partial evidence of the presence of a CE strategy. However the CE strategy phenomenon also has a philosophical component, represented by entrepreneurial strategic vision that accompanies and provides the value justification and stimulus for a pro-entrepreneurial organizational architecture as well as for entrepreneurial processes and behavior. By focusing on pro-entrepreneurship architecture it is demonstrated how CE can be manifested as an identifiable strategy, as inferable from the presence of patterns of entrepreneurial behavior as represented by dimensions of EO in the sample of firms selected for this study.

\subsection{Data collection and sampling}

The sampling frame for this study was based on a chamber of commerce membership list representative of businesses operating in the greater Johannesburg area. Johannesburg is situated in the Gauteng province, the economic hub of South Africa, which has the highest number of businesses (South African Business Guidebook 2005/6). This sampling frame, as identified from the Johannesburg Chamber of Commerce and Industry (JCCI) database of businesses operating in the greater Johannesburg area has a population of approximately 2600 firms (JCCI 2008). Based on SME eligibility criteria, in line with the global entrepreneurship monitor (GEM) studies' operational definitions (Bosma, Harding 
2006) ${ }^{1}$ and employing a non-probability judgemental sampling technique, 532 potential respondents were surveyed. Sample parameters, which served as control variables, included: (a) industrial sector, divided into four groups (manufacturing, professional services, wholesale/retail, and other services); (b) employment size class, divided into five groups (less than 5, 5-10, 11-50, 51-100, more than 100); (c) firm age (less than 3 months, 3-42 months, 5-10 years, 11-20 years, more than 20 years). The upper limit size criterion of a firm was set at 200 employees (here a single respondent still can report for entire firm), this upper limit set also allowed for filtering out of the largest firms, and presumably eliminated some of the typical organizational inertia characteristics of large firms, which may bias CE indicators (Davidsson 2004; Jantunen et al. 2005). The data collection procedure included telephone and e-mail surveys.

The target respondent was the owner-manager. Owner-mangers are typically well positioned in respect of overarching operational and strategic endeavors of the entire firm (Zahra, Covin 1995). Although regarded as a micro-level unit, the firm is an aggregate of different individuals and business activities, and the issues of relevance, size, size distributions, and heterogeneity need to be discussed (Davidsson 2004). Adhering to Stevenson's (1983) view of entrepreneurship as a management approach relevant to many different types of firms, it was vital to obtain a diverse sample. It is acknowledged that $\mathrm{CE}$ activities within corporations are heterogeneous. Moreover, CE may pay off in some contexts but not necessarily in others (Dess et al. 1997), consequently it has been suggested that researchers select a testing ground where there is strong theoretical reason to believe that opportunity-driven (as opposed to resource-driven) strategies lead to superior performance. Failure to attain predictive validity in such contexts would invalidate the measure.

Based on the relative heterogeneity of the several different industry sectors sampled, the generalizability of this study is strengthened. The important issue about sampling, in general, is not statistical but theoretical representativeness, i.e., the elements in the sample represents the type of phenomenon that the theory makes statements about (Davidsson 2004).

\subsection{Measures}

For the first phase of the study, EO was measured along the sub-dimensions of innovation, proactiveness, and risk taking (Covin, Slevin 1989; Covin et al. 2006; Lumpkin, Dess 2001; Khandwalla 1977; Kreiser et al. 2002; Miller, Friesen 1983). Based on the nine items constituting EO's three dimensions, the internal consistency of the sampling instrument, was assessed. A Cronbach's alpha (reliability coefficient) of 0.793 was calculated indicating a high reliability for the EO construct.

\footnotetext{
${ }^{1}$ Businesses in South Africa can be classified as micro, very small, small, or medium (SMME) according to a pre-determined set of thresholds. These thresholds are low by development-country norms. Many businesses regarded as SMME's in Europe and the United States (those with fewer than 500 employees) would be defined as large enterprises in South Africa. SMME's in South Africa can only employ up to 200 people (South Africa Survey 2006/2007). Only small and medium businesses were surveyed in this paper.
} 


\subsubsection{Independent variables}

Several instruments were scanned for relevance to this study, i.e., the entrepreneurial performance index (Morris, Kuratko 2002), the corporate entrepreneurship assessment instrument (Antoncic, Hisrich 2001; Morris, Kuratko 2002), the innovation climate questionnaire (Pinchot, Pellman 1999), and the organizational climate questionnaire (Litwin, Stringer 1968). Notwithstanding these measures, an instrument designed by Brown et al. (2001) to empirically gauge Stevenson's (1983) conceptualization of entrepreneurship as opportunity-based firm behavior, was used to measure the elements of organizational architecture. This instrument has been previously tested full scale on a very large (1200+ cases) stratified random sample of firms with different size, governance structure, and industry affiliation. This multidimensional measure reflects the conceptual discussions conducted earlier in this paper on pro-entrepreneurship architecture, as per the six subdimensions, which are labeled as strategic orientation, resource orientation, management structure, reward philosophy, growth orientation, and entrepreneurial culture.

Since it is difficult to develop a unified direct measure of CE strategy, and compare relative levels of CE strategy across contexts, or to study the causes and effects of entrepreneurship in mixed samples of firms, a clear advantage of this 20-item instrument is that it appears applicable across many different types of firms. A bi-polar 5-point scale was used to obtain responses on these sub-dimensions of pro-entrepreneurship architecture: namely, strategic orientation (3 items), resource orientation (4 items), management structure (5 items), reward philosophy (3 items), growth orientation (2 items), and entrepreneurial culture ( 3 items). A high score indicates a more pro-entrepreneurial element of organizational architecture.

To avoid response set contamination, questions were arranged so that entrepreneurial and non-entrepreneurial statements appeared on both the right and left sides of the scale. Additionally this measure has been shown to only partly overlap with EO instrument, since the CE strategy items gauge different and distinct aspects of entrepreneurship (Brown et al. 2001).

\subsubsection{Dependant variables}

Organizational-level outcomes of CE strategy were measured in terms of: (1) capability development, (2) strategic repositioning, and (3) absolute growth indicators.

Seven items were used to measure the first two CE strategy outcomes, where respondents were asked to what extent they agree or disagree $(1=$ strongly agree to $5=$ strongly disagree), with statements indicating levels of attaining capability and positioning.

Following the literature review, three common growth indicators were used: growth in (1) sales, (2) employees, (3) and equity. Although there is no consensus on the appropriate measure of firm growth, entrepreneurship researchers have pointed to multidimensional nature of growth as the crucial indicator of entrepreneurial success (Covin, Slevin 1997; Low, MacMillan 1998). Self-reported measures of sales, number of employees, and total equity, were surveyed. Five-point scales were used for all the growth measures, anchored by 'much less than' and 'much more than'. Absolute growth was simply computed as the size at 1 year minus the size of the previous year. 


\subsubsection{Control variables}

Consistent with previous studies control variables included industry sector, firm age and firm size (Covin, Slevin 1989; Lumpkin, Dess 2001); all three had a bearing on the sample selection process. All control variables have a prior theoretical basis for expecting the variable to have a systematic relationship with either the dependant or independent variable, or both (Wiklund, Shepherd 2005).

\section{Analytical techniques}

Diagnostics were carried out to test for normality of data. Results indicate that data is approximately normally distributed because the means, modes and medians for each question are almost equal. The Q-Q plots also support the normality of the data and the stem-and-leaf plots show a bell shape and all the significant values for the items are less than 0.05 indicating that the data is normally distributed and parametric tests could be conducted on this data set.

In testing the reliability of the six pro-entrepreneurial architecture dimensions it was found that not all the Cronbach Alphas exceeded the acceptable criterion level. Therefore an exploratory factor analysis with varimax rotation was used to identify the de facto underlying orthogonal dimensions of pro-entrepreneurial architecture evident in the data. Exploratory factor analysis was also used to obtain standardized (factor) scores for the dependent variables.

Multiple regression analyses, using ordinary least squares regression, were performed to determine the predicted relationship between the specified variables. The use of multiple regressions allows for the partitioning of variance with correlated predictors, thereby reducing the likelihood of making a Type 1 error (Cohen, Holliday 1998). Control variables were included in the regression analyses by means of the inclusion of appropriate dummy variable. Backwards stepwise regression was used to eliminate variables with insignificant regression coefficients. A significance level of 5\% was considered appropriate for this research and all statistical tests were carried out at this level.

A limitation of the article is that a cross-sectional study loses the dynamic aspects of CE strategy, which prevents conclusions about causal relationships to be drawn. Additionally, other contingencies not incorporated in the measurement instruments may influence the results.

\section{Results}

\subsection{First phase results: establishing EO levels}

For the first phase of the study, in order to select firms with higher levels of EO, the EO instrument was administered to all respondents. Based on the overall scores obtained on the EO scale, where higher scores are indicative of a greater EO, while lower scores are indicative of a more conservative orientation, 41 percent of the sampled firms were judged to have a higher level of EO, i.e., the average of the individual item scores was used as the scale score where this was greater than the midpoint (as measured per item on the 5-point bi-polar scale). To further verify the presence of an EO in this sample of SMEs, these firms were compared with sampling lists of firms with high rankings on 
industry reputational surveys regarding innovation and entrepreneurship-related matters over an extended period of time.

The Technology Top 100 survey (Financial Mail 2006) was used as a benchmark, since it showcases the technological prowess of South Africa's most innovative organizations. Here organizations are judged according to how the firm uses technology and innovation to achieve objectives, such as maximizing profits, gaining market share, creating niche markets or adding value for stakeholders (Financial Mail 2006). These metrics were scrutinized and served the purpose of assessing a firm's innovativeness, as firms with highly entrepreneurial CE strategy would score high on these metrics. By excluding cases with low levels of EO and also not featuring on these ranking lists, an effective sample of 203 SMEs was used for the main analysis.

To test for non-response bias (Armstrong, Overton 1977), firm size, age and sales growth were compared with non-responding firms by using secondary data obtained from the same Technology Top 100 survey (Financial Mail 2006). Results of $t$-tests comparing these firms with the current study sample's mean scores on the variables revealed no differences $(p>.10)$, suggesting that the sample appears to be representative of the population from which it is based, on these firm attributes.

The firm characteristics of the sample are presented in Table 1. Most of the firms (75 percent) are aged 5 years and above and only 25 percent were aged 42 months and below. The majority of the firms (67 percent) had less than 50 employees and 24 percent had more than 100 employees. Approximately 12 percent had less than 5 employees.

Table 1. Profile of SMEs

\begin{tabular}{cc}
\hline Characteristics of SME & Percentage \\
\hline Owner and manger run & $100 \%$ \\
\hline Firm age & $2 \%$ \\
\hline$<3$ months & $23 \%$ \\
\hline $3-42$ months & $64 \%$ \\
\hline $5-10$ years & $8 \%$ \\
\hline $11-20$ years & $3 \%$ \\
\hline$>20$ years \\
\hline Employee numbers \\
\hline$<5$ \\
\hline $5-10$ & $8 \%$ \\
\hline $11-50$ & $14 \%$ \\
\hline $51-100$ & $45 \%$ \\
\hline$>100$ & $9 \%$ \\
\hline SME sector & $24 \%$ \\
\hline Manufacturing & $13 \%$ \\
\hline Professional services & $19 \%$ \\
\hline Wholesale/retail & $58 \%$ \\
\hline Other services & $10 \%$ \\
\hline
\end{tabular}




\subsection{Phase 2: factor analysis}

Through the application of parallel analysis it was determined that four latent factors of pro-entrepreneurial architecture could be identified. The factor loadings are given in Table 2, together with the corresponding Cronbach Alphas, all of which exceeded the acceptable level (Nunnally 1978). Based on the survey items loading onto these factors, these factors have been labeled:

- Entrepreneurial strategic orientation and structure (this factor represents a consolidation of items which drive the creation of strategy where commitment to opportunity is related to strategic action and structure. Empirical linkages between structural organicity and the tendency of organizations to exhibit entrepreneurial behaviors have been demonstrated). Entrepreneurial culture (this factor represents the specific attributes of organizational cultures that support entrepreneurial behavior).

- Entrepreneurial growth and commitment to resources (this factor represents the growth orientation among executives subscribing to an entrepreneurial strategic vision that encourages acquiring resources that collectively promote entrepreneurial capability).

- Entrepreneurial reward philosophy (this factor is based on entrepreneurial visions that are likely to lead to reward systems that encourage entrepreneurial behaviors).

The internal consistency of each section was assessed through inter-item correlations and a Cronbach Alpha of 0.000 obtained for the overall scale indicating high reliability, which is above Nunnally's (1978) recommended level.

Table 2. Organizational architecture factor loadings after varimax rotation

\begin{tabular}{lcccc}
\hline \multicolumn{1}{c}{ Item } & $\begin{array}{c}\text { Factor 1 } \\
\text { Entrepreneurial } \\
\text { orientation and } \\
\text { structure }\end{array}$ & $\begin{array}{c}\text { Factor 2 } \\
\text { Entrepreneurial } \\
\text { culture }\end{array}$ & $\begin{array}{c}\text { Factor 3 } \\
\text { Entrepreneurial } \\
\text { growth and } \\
\text { commitment to } \\
\text { resources }\end{array}$ & $\begin{array}{c}\text { Factor 4 } \\
\text { Entrepreneurial } \\
\text { reward philosophy }\end{array}$ \\
\hline 1 & 2 & 3 & 4 & $*$ \\
\hline $\begin{array}{l}\text { Strategic } \\
\text { Orientation_1 }\end{array}$ & 0.5081 & $*$ & $*$ & $*$ \\
\hline $\begin{array}{l}\text { Strategic } \\
\text { Orientation_2 }\end{array}$ & $*$ & 0.5733 & $*$ & $*$ \\
\hline $\begin{array}{l}\text { Strategic } \\
\text { Orientation_3 }\end{array}$ & 0.5578 & $*$ & $*$ & $*$ \\
\hline $\begin{array}{l}\text { Resource } \\
\text { Orientation_1 }\end{array}$ & 0.6081 & $*$ & $*$ & $*$ \\
\hline $\begin{array}{l}\text { Resource } \\
\text { Orientation_2 }\end{array}$ & 0.5171 & $*$ & $*$ & $*$ \\
\hline $\begin{array}{l}\text { Resource } \\
\text { Orientation_3 }\end{array}$ & $*$ & $*$ & $*$ & $* 5118$ \\
\hline $\begin{array}{l}\text { Resource } \\
\text { Orientation_4 } \\
\text { Structure_1 }\end{array}$ & 0.6220 & $*$ & 0.5458 & $*$ \\
\hline
\end{tabular}


End of Table 2

\begin{tabular}{lcccc}
\hline \multicolumn{1}{c}{1} & 2 & 3 & 4 & 5 \\
\hline Structure_2 & 0.6448 & $*$ & 0.4266 & $*$ \\
\hline Structure_3 & 0.5590 & $*$ & $*$ & $*$ \\
\hline Structure_4 & 0.5819 & $*$ & $*$ & $*$ \\
\hline Structure_5 & 0.5969 & $*$ & $*$ & $* .6426$ \\
\hline $\begin{array}{l}\text { Reward } \\
\text { Philosophy_1 }\end{array}$ & 0.4257 & $*$ & $*$ & $*$ \\
\hline $\begin{array}{l}\text { Reward } \\
\text { Philosophy_2 }\end{array}$ & 0.5159 & $*$ & $*$ & $*$ \\
\hline $\begin{array}{l}\text { Reward } \\
\text { Philosophy_3 }\end{array}$ & $*$ & $*$ & $*$ & $*$ \\
\hline $\begin{array}{l}\text { Growth } \\
\text { Orientation_1 }\end{array}$ & $*$ & $* .5229$ & & $*$ \\
\hline $\begin{array}{l}\text { Growth } \\
\text { Orientation_2 }\end{array}$ & $*$ & $*$ & 0.5670 & $*$ \\
\hline Culture_1 & $*$ & $*$ & 0.4283 & $*$ \\
\hline Culture_2 & $*$ & 0.5572 & 0.4553 & 0.66 \\
\hline Culture_3 & $*$ & 0.85 & 0.71 & $*$ \\
\hline $\begin{array}{l}\text { Cronbach } \\
\text { alpha }\end{array}$ & & $*$ & & $*$ \\
\hline
\end{tabular}

Note: *Absolute values of factor loadings $<0.4$

It was determined a priori that there should be two organizational outcome factors. The factor loadings which define the factors Competitive Capability and Realization of Strategic Repositioning are given in Table 3, together with the corresponding Cronbach Alphas, all of which exceeded the acceptable level. Similarly, it was determined a priori that there should be three growth factors, and the resulting factor loadings on are given in Table 4, together with the corresponding acceptable Cronbach Alphas.

Table 3. Organizational outcome factor loadings after varimax rotation

\begin{tabular}{lcc}
\hline \multicolumn{1}{c}{ Variables } & $\begin{array}{c}\text { Factor 1 } \\
\text { Competitive Capability }\end{array}$ & $\begin{array}{c}\text { Factor 2 } \\
\text { Strategic Repositioning }\end{array}$ \\
\hline Exploit entrepreneurial opportunities & -0.6515 & $*$ \\
\hline Sustain viable position & -0.6742 & $*$ \\
\hline Explore new domains & -0.6922 & $*$ \\
\hline Exploit existing domains & -0.6519 & $*$ \\
\hline New position within pre-existing domain & $*$ & -0.4825 \\
\hline Alter the attributes of domains & $*$ & -0.6355 \\
\hline Assume new strategic position & $*$ & 0.68 \\
\hline Cronbach Alpha & 0.79 &
\end{tabular}

Note: *Absolute values of factor loadings $<0.4$ 
Table 4. Growth factor loadings after varimax rotation

\begin{tabular}{lccc}
\hline \multicolumn{1}{c}{ Variables } & $\begin{array}{c}\text { Factor 1 Sales } \\
\text { Growth }\end{array}$ & $\begin{array}{c}\text { Factor 2 Employee } \\
\text { Growth }\end{array}$ & $\begin{array}{c}\text { Factor 3 Equity } \\
\text { Growth }\end{array}$ \\
\hline PrevSalesGrow & 0.6838 & $*$ & $*$ \\
\hline RelatSalesGrow & 0.6964 & $*$ & $*$ \\
\hline PredSalesGrow & 0.4690 & $*$ & $*$ \\
\hline EmployeeGrow & $*$ & 0.7721 & $*$ \\
\hline PredEmployGrow & $*$ & 0.6366 & 0.5589 \\
\hline EquityGrow & $*$ & $*$ & 0.7184 \\
\hline PredEquityGrow & $*$ & $*$ & 0.68 \\
\hline Cronbach Alpha & 0.70 & 0.68 & \\
\hline
\end{tabular}

Note: *Absolute values of factor loadings $<0.4$

\subsection{Regression analysis}

The results of the regression analysis are summarized in Table 5. The regression formulae (all variables standardized) are as follows:

Competitive Capability $=0.0025$; Orientation / Structure $=-0.3958^{*}$; Culture $=$ $+0.1907 *$; Growth / Resources $=-0.2375^{*}$; Reward philosophy $=-0.1432 *$; Realization of Strategic Repositioning $=+0.8530$; Growth / Resources $=+0.2887^{*}$; Employees $=5$ to $10=-0.9811 ;$ Employees $=11$ to $50=-0.9889 ;$ Employees $=51$ to $100=-1.0056$; Employees $>100=-0.7928$; Sales Growth $=-1.6482$; Culture $=$ $+0.1983 *$; Firm Age $=3$ to 42 months $=+1.1621$; Firm Age $=5$ to 10 years $=+1.5085$; Firm Age $=11$ to 20 years $=+2.1249$; Firm Age $>20$ years $=+2.3847$; Employee Growth $=+0.0021$; Growth / Resources $=+0.3261 *$; Equity Growth $=+0.0067$; Culture $=+0.1796^{*}$; Reward philosophy $=+0.1802^{*}$.

Table 5 represents the independent variables regressed on the various dependent variables. It is worth noting that although the coefficients of determination $\left(\mathrm{R}^{2}\right)$ do not exceed 30 percent, the relationships determined through the regression analysis, while they may be weak, are nevertheless statistically significant - the $\mathrm{R}^{2}$ 's are given in Table 5. These results are interpreted as follows: For the first equation, the organizational elements (predictors) account for 25.6 percent variation in competitive capability. The sign of the regression coefficients provides an indication of the nature of the relationship between the variables under study, and in this instance a negative relationship is detected. For the second equation, only the growth/resources factor is a predictor in terms of organizational elements, but together with the control variable (number of employees) 18.9 percent is being accounted for in variation for the realization of strategic repositioning. Similarly for equation 3, culture is a predictor and control variables of firm age are accounting for 27 percent variation in sales growth. For equation 4, the growth/resources factor is the only predictor for employee growth and accounts for 10.7 percent variation. Equation 5 reveals that culture and reward philosophy are predictors of equity growth, accounting for 5.5 percent variation. 
Table 5. Regression equation section

\begin{tabular}{|c|c|c|c|c|c|}
\hline $\begin{array}{l}\text { Dependent variable } \\
\text { Independent } \\
\text { Variable }\end{array}$ & $\begin{array}{c}\text { Regression } \\
\text { Coefficient } \\
\mathrm{b}_{(\mathrm{i})}\end{array}$ & $\begin{array}{l}\text { Standard } \\
\text { Error } \\
\mathrm{S}_{\mathrm{b}(\mathrm{i})}\end{array}$ & $\begin{array}{c}\mathrm{T}-\text { Value } \\
\text { to test } \\
\mathrm{H}_{0}: \mathrm{B}_{(\mathrm{i})}=0\end{array}$ & $\begin{array}{l}\text { Prob } \\
\text { Level }\end{array}$ & $\begin{array}{c}\text { Reject } \\
\mathrm{H}_{0} \text { at } \\
5 \% ?\end{array}$ \\
\hline \multicolumn{6}{|c|}{ Competitive Capability $\left(\mathrm{R}^{2}=0.2560\right)$} \\
\hline Intercept & 0.0025 & 0.0712 & 0.036 & 0.9717 & No \\
\hline Orientation / Structure & -0.3958 & 0.0648 & 6.106 & 0.0000 & Yes \\
\hline Culture & 0.1907 & 0.0585 & 3.257 & 0.0013 & Yes \\
\hline Growth / Resources & -0.2375 & 0.0590 & 4.027 & 0.0001 & Yes \\
\hline Reward philosophy & -0.1432 & 0.0563 & 2.541 & 0.0118 & Yes \\
\hline \multicolumn{6}{|c|}{ Realization of Strategic Repositioning $\left(\mathrm{R}^{2}=0.1891\right)$} \\
\hline Intercept & 0.8530 & 0.2355 & -3.622 & 0.0004 & Yes \\
\hline Growth / Resources & 0.2887 & 0.0646 & 4.470 & 0.0000 & Yes \\
\hline$($ NoEmploy $=2)$ & -0.9811 & 0.2865 & 3.425 & 0.0008 & Yes \\
\hline$($ NoEmploy $=3)$ & -0.9889 & 0.2732 & 3.620 & 0.0004 & Yes \\
\hline$($ NoEmploy $=4)$ & -1.0056 & 0.3401 & 2.957 & 0.0035 & Yes \\
\hline$($ NoEmploy $=5)$ & -0.7928 & 0.2837 & 2.795 & 0.0057 & Yes \\
\hline \multicolumn{6}{|c|}{ Sales Growth $\left(\mathrm{R}^{2}=0.2701\right)$} \\
\hline Intercept & -1.6482 & 0.3636 & 4.533 & 0.0000 & Yes \\
\hline$($ FirmAge $=2)$ & 1.1621 & 0.4026 & -2.887 & 0.0043 & Yes \\
\hline$($ FirmAge $=3)$ & 1.5085 & 0.3857 & -3.911 & 0.0001 & Yes \\
\hline$($ FirmAge $=4)$ & 2.1249 & 0.4172 & -5.093 & 0.0000 & Yes \\
\hline$($ FirmAge $=5)$ & 2.3847 & 0.3977 & -5.997 & 0.0000 & Yes \\
\hline Culture & 0.1983 & 0.0642 & -3.091 & 0.0023 & Yes \\
\hline \multicolumn{6}{|c|}{ Employee Growth $\left(\mathrm{R}^{2}=0.1079\right)$} \\
\hline Intercept & 0.0021 & 0.0818 & 0.025 & 0.9797 & No \\
\hline Growth / Resources & 0.3261 & 0.0670 & 4.868 & 0.0000 & Yes \\
\hline \multicolumn{6}{|c|}{ Equity Growth $\left(\mathrm{R}^{2}=0.0557\right)$} \\
\hline Intercept & 0.0067 & 0.0903 & 0.074 & 0.9408 & No \\
\hline Culture & 0.1796 & 0.0742 & 2.420 & 0.0165 & Yes \\
\hline Reward philosophy & 0.1802 & 0.0715 & -2.520 & 0.0125 & Yes \\
\hline
\end{tabular}

The results indicate significant regression coefficients between the factors of pro-entrepreneurship architecture and capability development, strategic repositioning, and growth indicators which provide support for the hypothesis. Given that the results are modest in terms of the explanatory power obtained in the regression models, means the strength of the relationships between various elements of pro-entrepreneurship architecture and 
outcomes are generally weak and mostly positive. The negative relationship detected in terms of competitive capability and factors of orientation/structure and growth/resources and reward philosophy suggests that, unlike in large firms, in SMEs these factors may have a reverse effect on outcomes. Plausible reasons for this are that the capacity for SMEs to create and sustain economically viable industry positions is limited, particularly in an emerging market context. Another contribution worth noting is that although the realization of strategy as an outcome is effected by the growth/resources factor, other predictors in terms of employment numbers, particularly as they increase in number, may also account for variation in this outcome. In terms of sales growth the predictors are culture, while all specified predictors influence firm age, and also show a steady increase as firm age increases.

\section{Discussion}

The purpose of this article was to empirically test elements of the pro-entrepreneurship organizational architecture in terms of principal outcomes. In line with the view that CE can be regarded as a specific type of strategy (Ireland et al. 2009), where firms must significantly display the elements of an entrepreneurial strategic vision (operationalized as EO in the present study), it was hypothesized that various elements of pro-entrepreneurship architecture will positively influence organizational outcomes.

Our core contribution is based on the empirical evidence ensuing from this study and indicates that all of the factors of pro-entrepreneurship architecture predict outcomes to some extent.

Our results resonate with established findings. Empirical linkages between structural organicity or aspects of structural organicity and the tendency of organizations to exhibit entrepreneurial behaviors have been demonstrated by, for example, Miller and Friesen (1984), Covin and Slevin (1988), and Barrett and Weinstein (1998). This present study confirms these linkages where significant coefficients were detected on competitive capability outcomes. While many structural attributes have been empirically linked to innovation activity in organizations (Lawrence, Lorsch 1967; Mintzberg 1979), perhaps the single aspect of structure that best defines entrepreneurial organizations is structural organicity. Greater organicity implies a proclivity toward such qualities as decentralized decision making, low formality, wide spans of control, expertise- (vs. position-) based power, process flexibility, free-flowing information networks, and loose adherence to rules and policies. By providing insight into the structure of firm capabilities, Bingham, Eisenhardt and Furr (2007) show that organizational heuristics are at the heart of high performing organizational processes.

In terms of the entrepreneurial growth/resource factor and its effect on outcomes, of particular relevance is the accumulation of resources and the capabilities, which enable SMEs to collectively promote entrepreneurial capability (Kuratko, Welsch 2001). As opportunities drive strategy, almost any opportunity is relevant to the firm. Once an opportunity is identified, resources are needed to exploit it (Huy 2001; Stevenson 1983). The accumulation of resources and the capabilities SMEs enable reflect an entrepre- 
neurial strategic vision that will likely encourage acquiring resources that collectively promote an entrepreneurial capability.

We acknowledge another factor playing a role in SME outcomes is reward philosophy. In particular, whether or not the reward system encourages risk taking and innovation seems to have a direct affect on tendencies to behave in an entrepreneurial manner. Whether formal or informal, reward systems will likely be influenced by the vision managers articulate for their organizations. Hence, consistent with the observations of Collins and Porras (1996), entrepreneurial visions are likely to lead to reward systems that encourage entrepreneurial behaviors. Research is pervasive on cultural norms encouraging entrepreneurial behavior, such as having a tolerance for risks and allowing for mistakes and failure (Hisrich, Peters 2002; Kuratko, Hornsby 1998; Kuratko, Welsch 2001). Our contribution highlights when SMEs undertake corporate entrepreneurial activities which render dynamic capabilities, they lead to sustainable competitive advantages, which are reflected in firm performance (Yiu, Lau 2008).

On a broader level, past research has highlighted that $\mathrm{CE}$ is key for emerging economy firms to revitalize, reconfigure resources which are able to transform into market-orientated firms able to compete globally (Yiu, Lau 2008). For businesses based in Africa, the challenge to participate in the global economy of the $21^{\text {st }}$ century will be to compete as world-class businesses where the focus is on high-value added human capital based on creativity and innovation (Luiz 2006).

It is noteworthy to recognize that the relevance of CE to small business remains contestable. When applied against the classic definition of entrepreneurship, in terms of the identification and exploitation of opportunity in the face of resource constraints, CE is a contradiction in terms, according to Phan et al. (2009). Relative to emergent firms, corporations are replete with human and financial capital, and possess large networks from which managers can draw ideas, technology, and raw materials to bring their business ideas to fruition. Moreover, the relatively comprehensive environmental scanning capabilities of corporations function to mitigate the risks of mis-identifying opportunities. However, it has been acknowledged that the process of exploiting new opportunities in corporations is fraught with the same risks as those facing start ups. This is ascribed to the outcomes of innovation, which is a core entrepreneurial activity, and is difficult to predict (Phan et al. 2009).

\section{Implications for research and practice}

By focusing research on CE strategy in SMEs, small business owners are now able to identify and distinguish between different elements of pro-entrepreneurship architecture that impact different firm outcomes. These business owners will be able to understand how resources and internal structures, in particular, contribute towards entrepreneurial outcomes. Resource configurations may provide indications in terms of strategy direction and entrepreneurial posture. The strategic implications of this study suggest that SMEs resourcing and rewarding policies, as well as cultural and structural orientations, derived from a CE strategy, play an important role in realizing firm outcomes. More- 
over, as Kleinbaum and Tushman (2007) suggest that interdivisional innovations are driven primarily by social networks, it is recommended that SMEs with a CE strategy focus engage in networking which allows entrepreneurs to enlarge their knowledge of opportunities, to gain access to critical resources, and to deal with business obstacles (Adler, Kwon 2002).

A deep and thorough understanding of CES is important not only for academic purposes but also because the subject has salience for practitioners and policy makers. These implications relate to the profitability and competitiveness of the firm as well as to the overall economic performance of industry and the national economy. As part of government initiatives in emerging countries, which is often to foster innovation, policies should encourage the diffusion, adoption and application of the very latest technologies, often the cornerstones of innovation, since a lot of potential exists in emerging countries to import and adapt technologies developed in industrialized countries (Von Broembsen et al. 2005).

Generally, research in Africa as a whole may be considered as valuable, as very few empirical studies have been previously conducted which focus on CE strategy. In developing economies where growth is often the primary goal of organizations, CE in firms can be particularly critical for firm profitability and survival (Antoncic, Hisrich 2001). The majority of research in EO and CE has been conducted in the United States, and with the relevance of international entrepreneurship being recognized (Jantunen et al. 2005), the importance of further interrogating CEs in an emerging country context seems justifiable. Such investigations allow researchers to compare and examine different CE strategy which SMEs use in similar environmental contexts. Recent research finds that intrapreneurship and independent entrepreneurship seem to be substitutes at the macro level. Large firms in high income countries tend to display more entrepreneurial behavior than large firms in low income countries (Bosma et al. 2010). Much CE research focuses on large corporations and upon the manufacturing sector, particularly in relation to high technology sectors. Yet, SMEs may also involve scope for significant CE. There is a need for further theorization and empirical analysis of these different contexts.

\section{References}

Adler, P. S.; Kwon, S. W. 2002. Social capital: prospects for a new concept, Academy of Management Review 27: 17-40.

Aloulou, W.; Faylolle, A. 2005. A conceptual approach of entrepreneurial orientation within small business context, Journal of Enterprising Culture 13: 21-45.

http://dx.doi.org/10.1142/S0218495805000045

Anderson, B. S.; Covin, J. G.; Slevin, D. P. 2009. Understanding the relationship between entrepreneurial orientation and strategic learning capability: an empirical investigation, Strategic Entrepreneurship Journal 3: 218-240. http://dx.doi.org/10.1002/sej.72

Antoncic, B. 2006. Impacts of diversification and corporate entrepreneurship strategy making on growth and profitability: a normative model, Journal of Enterprising Culture 14: 49-63.

http://dx.doi.org/10.1142/S0218495806000040

Antoncic, B.; Hisrich, R. D. 2001. Intrapreneurship: construct refinement and cross-cultural validation, Journal of Business Venturing 16(5): 495-527.

http://dx.doi.org/10.1016/S0883-9026(99)00054-3 
Antoncic, B.; Hisrich, R. D. 2004. Corporate entrepreneurship contingencies and organizational wealth creation, Journal of Management Development 23(6): 518-550.

http://dx.doi.org/10.1108/02621710410541114

Armstrong, J. S.; Overton, T. S. 1977. Estimating non-response bias in mail surveys, Journal of Marketing Research 14: 396-402. http://dx.doi.org/10.2307/3150783

Arslan, Ö.; Karan, M. B. 2009. Credit risks and internationalization of SMEs, Journal of Business Economics and Management 10(4): 361-368. http://dx.doi.org/10.3846/1611-1699.2009.10.361-368

Barney, J. B. 1991. Firm resources and sustained competitive advantage, Journal of Management 17: 99-120. http://dx.doi.org/10.1177/014920639101700108

Barrett, H.; Weinstein, A. 1998. The effect of market orientation and organizational flexibility on corporate entrepreneurship, Entrepreneurship Theory and Practice 23(1): 57-70.

Bartlett, C. A.; Goshal, S. 1996. Release the entrepreneurial hostages from your corporate hierarchy, Strategy and Leadership 24(4): 36-42. http://dx.doi.org/10.1108/eb054563

Bettis, R. A.; Prahalad, C. K. 1995. The dominant logic: retrospective and extension, Strategic Management Journal 16: 5-14. http://dx.doi.org/10.1002/smj.4250160104

Bingham, C. B.; Eisenhardt, K. M.; Furr, N. R. 2007. What make a process a capability? Heuristics, strategy, and effective capture of opportunities, Strategic Entrepreneurship Journal 1: 27-47. http://dx.doi.org/10.1002/sej.1

Borch, O. J.; Huse, M.; Senneseth, K. 1999. Resource configuration, competitive strategies, and corporate entrepreneurship: an empirical examination of small firms, Entrepreneurship Theory and Practice (Fall): 49-70.

Bosma, N.; Harding, R. 2006. Global Entrepreneurship Monitor. GEM 2006 Results. Babson and London Business School.

Bosma, N.; Stam, E.; Wennekers, S. 2010. Intrapreneurship - an International Study. EIM Research Report Intrapreneurship. Dutch Ministry of Economic Affairs.

Brown, T.; Davidsson, P.; Wiklund, J. 2001. An Operalization of Stevenson's conceptualisation of entrepreneurship as opportunity-based firm behavior, Strategic Management Journal 22: 953-968. http://dx.doi.org/10.1002/smj.190

Burns, P. 2004. Corporate Entrepreneurship: Building an Entrepreneurial Organization. Palgrave Macmillan: Basingstoke.

Camisón, C.; Villar-López, A. 2010. Effect of SMEs' international experience on foreign intensity and economic performance: the mediating role of internationally exploitable assets and competitive strategy, Journal of Small Business Management 48(2): 116-151.

http://dx.doi.org/10.1111/j.1540-627X.2010.00289.x

Cohen, L.; Holliday, M. 1998. Practical Statistics for Students. London: Paul Chapman Publishing. Collins, J. C.; Porras, J. I. 1996. Building your company's vision, Harvard Business Review 74(6): 65-77.

Covin, J. G.; Green, K. M.; Slevin, D. P. 2006. Strategic process effects on the entrepreneurial orientation-sales growth rate relationship, Entrepreneurship Theory and Practice (January): 57-81. http://dx.doi.org/10.1111/j.1540-6520.2006.00110.x

Covin, J. G.; Kuratko, D. F. 2008. The concept of corporate entrepreneurship, in Narayanan V.; O'Connor, G (Eds.). The Blackwell Encyclopedia of Technology and Innovation Management. Oxford, UK: Blackwell Publishers.

Covin, J. G.; Miles, M. P. 1999. Corporate entrepreneurship and the pursuit of competitive advantage, Entrepreneurship Theory and Practice 23(3): 47-63.

Covin, J. G.; Miles, M. P. 2007. Strategic use of corporate venturing, Entrepreneurship Theory and Practice 31(2): 183-207. http://dx.doi.org/10.1111/j.1540-6520.2007.00169.x 
Covin, J. G.; Slevin, D. P. 1988. The influence of organization structure on the utility of an entrepreneurial top management style, Journal of Management Studies 25(3): 217-234.

http://dx.doi.org/10.1111/j.1467-6486.1988.tb00033.x

Covin, J. G.; Slevin, D. P. 1989. Strategic planning of small firms in hostile and benign environments, Strategic Management Journal 10: 75-87. http://dx.doi.org/10.1002/smj.4250100107

Covin, J. G.; Slevin, D. P. 1991. A conceptual model of entrepreneurship as firm behavior, Entrepreneurship Theory and Practice 16: 7-26.

Covin, J. G.; Slevin, D. P. 1997. High growth transitions: theoretical perspectives and suggested directions, in Sexton, D. L.; Smilor, R. W. (Eds.). Entrepreneurship 2000. Chicago: Upstart Publishing Co, 99-126.

Covin, J. G.; Slevin, D. P. 2002. The entrepreneurial imperatives of strategic leadership, in Hitt, M. A.; Ireland, R. D.; Camp, S. M.; Sexton, D. L. (Eds.). Strategic Entrepreneurship: Creating a New Mindset. Oxford, UK: Blackwell Publishers, 309-327.

Davidsson, P. 2004. Researching Entrepreneurship, International Studies in Entrepreneurship. Springer. New York.

Dess G. G.; Ireland, R. D.; Zahra, S. A.; Floyd, S. W.; Janney, J. J.; Lane, P. J. 2003. Emerging issues in corporate entrepreneurship, Journal of Management 29: 351-378.

http://dx.doi.org/10.1002/(SICI)1097-0266(199710)18:9<677::AID-SMJ905>3.0.CO;2-Q

Dess, C. G.; Lumpkin, G. T.; Covin, J. G. 1997. Entrepreneurial strategy making and firm performance: tests of contingency and configurational models, Strategic Management Journal 18(9): 677-695. http://dx.doi.org/10.5465/AME.2005.15841975

Dess, G. G.; Lumpkin, G. T. 2005. The role of entrepreneurial orientation in stimulating effective corporate entrepreneurship, Academy of Management Executive 19(1): 147-156.

Dess, G. G.; Lumpkin, G. T.; McGee, J. E. 1999. Linking corporate entrepreneurship to strategy, structure, and process: suggested research directions, Entrepreneurship Theory and Practice (Winter): 85-101.

Drucker, P. 1979. The Practice of Management. London: Pan books Ltd.

Eisenhardt, K. M.; Brown, S. L.; Neck, H. M. 2000. Competing on the entrepreneurial edge, in Meyer, G. D.; Heppard, K. A. (Eds.). Entrepreneurship as Strategy. Thousand Oaks, CA: Sage Publications, 49-62.

Financial Mail. 2006. Innovations, Technology Top 100, Financial Mail (December) 01: 5-18.

Geisler, E. 1993. Middle managers as internal corporate entrepreneurs, Interface 23(6): 52-63. http://dx.doi.org/10.1287/inte.23.6.52

Green, K. M.; Covin, J. G.; Slevin, D. P. 2008. Exploring the relationship between strategic reactiveness and entrepreneurial orientation: the role of structure-style fit, Journal of Business Venturing 23: 356-383. http://dx.doi.org/10.1016/j.jbusvent.2007.01.002

Grüner, H. 2006. Entrepreneurship in Germany and the role of the new self-employed, Journal of Business Economic Management VII(2): 59-67.

Guth, W. D.; Ginsberg, A. 1990. Corporate entrepreneurship, Strategic Management Journal 11(Special Issue): 5-15.

Hamel, G. 2000. Leading the Revolution. Cambridge, MA: Harvard University Press.

Hamel, G.; Prahalad, C. K. 1989. Strategic intent, Harvard Business Review 67(3): 67-76.

Hisrich, R. D.; Peters, M. P. 2002. Entrepreneurship. 5th ed. Boston, MA: McGraw-Hill.

Hitt, M. A.; Ireland, R. D.; Camp, S. M.; Sexton, D. L. 2002. Strategic Entrepreneurship: Creating a New Mindset. Oxford, UK: Blackwell Publishing.

Hornsby, J. S.; Kuratko, D. F.; Zahra, S. A. 2002. Middle managers' perception of the internal 
environment for corporate entrepreneurship: assessing a measurement scale, Journal of Business Venturing 17(3): 253-273. http://dx.doi.org/10.1016/S0883-9026(00)00059-8

Huy, Q. N. 2001. In praise of middle managers, Harvard Business Review 79(8): 72-79.

Ireland, R. D.; Covin, J. G.; Kuratko, D. F. 2009. Conceptualizing corporate entrepreneurship strategy, Entrepreneurship Theory and Practice (January): 19-46.

http://dx.doi.org/10.1111/j.1540-6520.2008.00279.x

Ireland, R. D.; Hitt, M. A.; Sirmon, D. G. 2003. A model of strategic entrepreneurship: the construct and its dimensions, Journal of Management 29(6): 963-989.

http://dx.doi.org/10.1016/j.bushor.2006.06.002

Ireland, R. D.; Webb, J. W. 2007. Strategic entrepreneurship: creating competitive advantage through streams of innovation, Business Horizons 50(1): 49-59.

Jantunen, A. K.; Puumalainen, S.; Saarenketo, S.; Kylaheiko, K. 2005. Entrepreneurial orientation, dynamic capabilities and international performance, Journal of International Entrepreneurship 3: 223-243. http://dx.doi.org/10.1007/s10843-005-1133-2

JCCI [online] 2008 [cited 21 April 2008]. Available from Internet: http//.www.jcci.co.za/index/html Jumpponen, J.; Ikävalko, M.; Pihkala, T. 2008. Management and change in turbulent times: how do Russian small business managers perceive the development of their business environment?, Journal of Business Economics and Management 9(2): 115-122.

http://dx.doi.org/10.3846/1611-1699.2008.9.115-122

Kellermanns, F. W.; Eddleston, K. 2006. Corporate entrepreneurship in family firms: a family perspective, Entrepreneurship Theory and Practice (November): 809-830.

http://dx.doi.org/10.1111/j.1540-6520.2006.00153.x

Ketchen, D. J.; Ireland, R. D.; Snow, C. C. 2007. Strategic entrepreneurship, collaborative innovation and wealth creation, Strategic Entrepreneurship Journal 1: 371-385.

http://dx.doi.org/10.1002/sej.20

Khandwalla, P. N. 1977. The Design of Organizations. New York: Harcourt Inc.

Kleinbaum, A. M.; Tushman, M. L. 2007. Building bridges: the social structure of interdependent innovation, Strategic Entrepreneurship Journal 1: 103-122. http://dx.doi.org/10.1002/sej.14

Knight, G. A. 1997. Cross-cultural reliability and validity of a scale to measure firm entrepreneurial orientation, Journal of Business Venturing 12: 213-225.

http://dx.doi.org/10.1016/S0883-9026(96)00065-1

Kogut, B.; Zander, U. 1992. Knowledge of the firm, combinative capabilities, and the replication of technology, Organization Science 3(3): 383-397. http://dx.doi.org/10.1287/orsc.3.3.383

Kreiser, P. M.; Marino, L. D.; Weaver, M. K. 2002. Assessing the psychometric properties of the entrepreneurial orientation scale: a multi country analysis, Entrepreneurship Theory and Practice (Spring): 71-94.

Kuratko, D. F. 2002. Corporate Entrepreneurship. Harcourt College Publishers: USA. http://dx.doi.org/10.1111/j.1540-6520.2008.00278.x

Kuratko, D. F.; Audretsch, D. B. 2009. Strategic entrepreneurship: exploring different perspectives of an emerging concept, Entrepreneurship Theory and Practice 33(1): 1-17.

http://dx.doi.org/10.1177/107179199900500204

Kuratko, D. F.; Hornsby, J. S. 1998. Corporate entrepreneurial leadership for the 21 st century, Journal of Leadership Studies 5(2): 27-39.

Kuratko, D. F.; Hornsby, J. S.; Goldsby, M. G. 2004. Sustaining corporate entrepreneurship: a proposed model of perceived implementation/outcome comparisons at the organizational and individual levels, International Journal of Entrepreneurship and Innovation 5(2): 77-89.

http://dx.doi.org/10.5367/000000004773863237 
Kuratko, D. F.; Hornsby, J. S.; Naffziger, D. W.; Montangno, R. V. 1993. Implement entrepreneurial thinking in established organizations, SAM Advanced Management Journal 58(1): 28-39.

Kuratko, D. F.; Ireland, R. D.; Hornsby, J. S. 2001. Improving firm performance through entrepreneurial actions: corporate entrepreneurship strategy, Academy of Management 15: 60-71.

Kuratko, D. F.; Welsch, H. P. 2001. Strategic Entrepreneurial Growth. Harcourt College: Fort Worth, TX.

Latham, S. 2009. Contrasting strategic response to economic recession in start-up versus established software firms, Journal of Small Business Management 47(2): 180-201.

http://dx.doi.org/10.1111/j.1540-627X.2009.00267.x

Lawrence, P. R.; Lorsch, J. W. 1967. Organization and Environment: Managing Differentiation and Integration. Boston: Graduate School of Business Administration, Harvard University.

Lee, S. M.; Peterson, S. J. 2000. Culture, entrepreneurial orientation, and global competitiveness, Journal of World Business 35: 401-415. http://dx.doi.org/10.1016/S1090-9516(00)00045-6

Litwin, G. H.; Stringer, R. A. 1968. Motivation and Organizational Climate. Boston: Harvard University Press.

Low, M.; Macmillan, I. 1998. Entrepreneurship: past research and future challenges, Journal of Management 14: 139-161. http://dx.doi.org/10.1177/014920638801400202

Luiz, J. 2006. Managing Business in Africa. Practical Management Theory for an Emerging Market. South Africa: Oxford University Press.

Lumpkin, G. T.; Dess, D. G. 1996. Clarifying the entrepreneurial orientation construct and linking it to performance, Academy of Management Review 21: 135-166.

http://dx.doi.org/10.1016/S0883-9026(00)00048-3

Lumpkin, G. T.; Dess, G. G. 2001. Linking two dimensions of entrepreneurial orientation to firm performance: the moderating role of environment and industry life cycle, Journal of Business Venturing 16: 429-451.

Marino, L.; Strandholm, H. K.; Steensma, K. H.; Weaver, M. K. 2002. The moderating effect of national culture on the relationship between entrepreneurial orientation and strategic alliance portfolio extensiveness, Entrepreneurship Theory and Practice (Summer): 145-160.

Merz, G. R.; Sauber, M. H. 1995. Profiles of managerial activities in small firms, Strategic Management Journal 16: 551-564. http://dx.doi.org/10.1002/smj.4250160705

Messeghem, K. 2003. Strategic entrepreneurship and managerial activities in SMEs, International Small Business Journal 21: 197-212. http://dx.doi.org/10.1177/0266242603021002004

Meyer, G. D.; Heppard, K. A. 2000. Entrepreneurship as Strategy. Thousand Oaks, CA: Sage Publications.

Miller, D.; Friesen, P. H. 1983. Innovation in conservative and entrepreneurial firms: two models of strategic momentum, Strategic Management Journal 3: 1-25.

http://dx.doi.org/10.1002/smj.4250030102

Miller, D.; Friesen, P. H. 1984. Organizations: A Quantum View. Englewood Cliffs, NJ: Prentice Hall.

Mintzberg, H. 1979. The Structuring of Organizations. Englewood Cliffs, NJ: Prentice Hall.

Mintzberg, H. 1987. The strategy concept I: five P's for strategy, California Management Review 30(1): 11-24.

Morris, M.; Davis, D. L.; Allen, J. W. 1994. Fostering corporate entrepreneurship: cross cultural comparisons of the importance of individualism versus collectivism, Journal of International Business Studies 25: 65-90. http://dx.doi.org/10.1057/palgrave.jibs.8490849

Morris, M. H.; Kuratko, D. F. 2002. Corporate Entrepreneurship. Florida: Harcourt College Publishers. 
Morris, M. H.; Kuratko, D. F.; Covin, J. G. 2008. Corporate Entrepreneurship and Innovation. Cincinnati, OH: Thomson/Southwestern Publishers.

Muzyka, D.; De Koning, A.; Churchill, N. 1995. On transformation and adaptation: building the entrepreneurial corporation, European Management Journal 13(4): 346-362.

http://dx.doi.org/10.1016/0263-2373(95)00029-K

Nelson, R. R. 1991. Why do firms differ and how does it matter?, Strategic Management Journal 12 (Winter Special Issue): 61-74.

Newbert, S. L.; Kirchoff, A. B.; Walsh, S. T. 2007. Defining the relationship among founding resources, strategies, and performance in technology-intensive new ventures: evidence from the semiconductor silicon industry, Journal of Small Business Management 45(4): 438-466.

http://dx.doi.org/10.1111/j.1540-627X.2007.00222.x

Nunnally, J. C. 1978. Psychometric Theory. 2nd ed. New York: McGraw-Hill.

Phan, P. H.; Wright, M.; Ucbasaran, D.; Tan, W. L. 2009. Corporate entrepreneurship: current research and future directions, Journal of Business Venturing 10: 10-16.

Phelps, E. 2009. Thoughts on a crisis. Future of capitalism. Debate, Financial Times May 12.

Pinchot, G. 1985. Intrapreneuring: Why You Don't Have to Leave the Corporation to Be an Entrepreneur. New York: Harper and Row.

Pinchot, G.; Pellman, R. 1999. Intrapreneuring in Action: a Handbook for Business Innovation. San Francisco: Berret-Koehler.

Russell, R. D.; Russell, C. J. 1992. An examination of the effects of organisational norms, organizational structure, and environmental uncertainty on entrepreneurial strategy, Journal of Management 18(4): 639-656. http://dx.doi.org/10.1177/014920639201800403

Schindehutte, M.; Morris, M. H. 2009. Advancing strategic entrepreneurship research: the role of complexity science in shifting the paradigm, Entrepreneurship Theory and Practice (January): 241-276. http://dx.doi.org/10.1111/j.1540-6520.2008.00288.x

Schindehutte, M.; Morris, M. H.; Kuratko, D. F. 2000. Triggering events, corporate entrepreneurship and the marketing function, Journal of Marketing Theory and Practice 8(2): 18-20.

Schumpeter, J. A. 1934. The Theory of Economic Development. Cambridge, MA: Harvard University Press.

Shane, S.; Venkataraman, S. 2000. The promise of entrepreneurship as a field of research, Academy of Management Review 25: 217-226.

Sharma, P.; Chrisman, J. J. 1999. Reconciling the definitional issues in the field of corporate entrepreneurship, Entrepreneurship Theory and Practice 23(3): 11-26.

Shepherd, D.; Wiklund, J. 2009. Are we comparing apples with apples or apples with oranges? Appropriateness of knowledge accumulation across growth studies, Entrepreneurship Theory and Practice 33(1):105-123. http://dx.doi.org/10.1111/j.1540-6520.2008.00282.x

Sirmon, D. G.; Hitt, M. A.; Ireland, R. D. 2007. Managing firm resources in dynamic environments to create value: looking inside the black box, Academy of Management Review 32(1): 273-292. http://dx.doi.org/10.5465/AMR.2007.23466005

South Africa Business Guidebook. 2005/6. Your Essential A-Z Business Resources with an Investment Focus. 9th ed. South Africa: Write Stuff Publishing.

Steffens, P.; Davidsson, P. P.; Fitzsimmons, J. 2009. Performance configurations over time: implications for growth- and profit-oriented strategies, Entrepreneurship Theory and Practice (January): 125-148. http://dx.doi.org/10.1111/j.1540-6520.2008.00283.x

Stevenson, H. H. 1983. A perspective on entrepreneurship, Harvard Business School Working Paper 9-384-131. 
Stevenson, H. H.; Gumpert, G. 1985. The heart of entrepreneurship, Harvard Business Review 63(2): 85-94.

Stevenson, H. H.; Jarillo, J. C. 1986. Preserving entrepreneurship as companies grow, Journal of Business Strategy 6: 10-23. http://dx.doi.org/10.1108/eb039138

Stevenson, H. H.; Jarillo, J. C. 1990. A paradigm of entrepreneurship: entrepreneurial management, Strategic Management Journal (Summer Special Issue) 11: 17-27.

Tan, J.; Fischer, E.; Mitchell, R.; Phan, P. 2009. At the centre of the action: innovation and technology strategy research in the small business setting, Journal of Small Business Management 47(3): 233-262. http://dx.doi.org/10.1111/j.1540-627X.2009.00270.x

Tang, L.; Koveos, P. E. 2004. Venture entrepreneurship, innovation entrepreneurship, and economic growth, Journal of Developmental Entrepreneurship 9: 161-171.

Teece, D. J.; Pisano, G.; Shuen, A. 1997. Dynamic capabilities and strategic management, Strategic Management Journal 18: 509-533.

http://dx.doi.org/10.1002/(SICI)1097-0266(199708)18:7<509::AID-SMJ882>3.0.CO;2-Z

Urban, B. 2008. Entrepreneurship orientation in a developing country context: juxtapositions with South Africa's innovation index, Journal of Developmental Entrepreneurship 13(4): 425-433. http://dx.doi.org/10.1142/S108494670800106X

Urban, B. 2010a. Competitive strategies for technology entrepreneurs: links to environmental dynamism and hostility, International Journal of Entrepreneurship and Innovation 11(1): 69-77. http://dx.doi.org/10.5367/000000010790772421

Urban, B. 2010b. A focus on networking practices for entrepreneurs in a transition economy, Transformations in Business and Economies 9(3): 52-66.

Von Broembsen, M.; Wood, E.; Herrington, M. 2005. Global Entrepreneurship Monitor, South African Report. Graduate School of Business: University of Cape Town.

Wiklund, J. 1999. The sustainability of the entrepreneurial orientation-performance relationship, Entrepreneurship Theory and Practice 24: 37-50. http://dx.doi.org/10.1002/smj.360

Wiklund, J.; Shepherd, D. 2003. Knowledge based resources, entrepreneurial orientation, and the performance of small and medium sized businesses, Strategic Management Journal 24: 13071314. http://dx.doi.org/10.1016/j.jbusvent.2004.01.001

Wiklund, J.; Shepherd, D. 2005. Entrepreneurial orientation and small business performance: a configurational approach, Journal of Business Venturing 20(1): 71-91.

Yiu, D. W.; Lau, C. M. 2008. Corporate entrepreneurship's resource capital configuration in emerging market firms, Entrepreneurship Theory and Practice (January): 37-57.

Zahra, S. 1991. Predictors and financial outcomes of corporate entrepreneurship: an explorative study, Journal of Business Venturing 6: 259-285. http://dx.doi.org/10.1016/0883-9026(91)90019-A

Zahra, S. 1993. A conceptual model of entrepreneurship as firm behaviour: a critique and extension, Entrepreneurship Theory and Practice 16: 5-21.

Zahra, S. A.; Covin, J. G. 1995. Contextual influences on the corporate entrepreneurship - performance relationship: a longitudinal analysis, Journal of Business Venturing 10: 43-58.

http://dx.doi.org/10.1016/0883-9026(94)00004-E

Zahra, S. A.; Ireland, R. D.; Gutierrez, I.; Hitt, M. A. 2000. Privatization and entrepreneurial transformation: emerging issues and a future research agenda, The Academy of Management Review 25(3): 509-524.

Zahra, S. A.; Jennings, D. F.; Kuratko, D. F. 1999. The antecedents and consequences of firmlevel entrepreneurship: the state of the field, Entrepreneurship Theory and Practice 24(2): 45-65. 
Boris URBAN is a Professor at the Graduate School of Business Administration, Wits Business School (WBS), Faculty of Commerce, Law and Management, University of Witwatersrand. He has more than 30 years academic and professional experience in business, where he has practiced, taught and researched strategy, organizational behavior and entrepreneurship. Since 2009 Boris has held the Chair in Entrepreneurship (Lamberti Foundation) at the WBS. Boris has many scholarly peer reviewed publications in leading journals, featuring ISI and Financial Times Top 20 ranked journals. He is the series editor and author of 'Perspectives in Entrepreneurship: a Research Companion' published by Springer Books internationally and Pearson Publishers. Professor Urban is a National Research Foundation (NRF) rated researcher. 